\title{
Transpleural Gradient of 1,25-Dihydroxyvitamin D in Tuberculous Pleuritis
}

Peter F. Barnes, ${ }^{\star}$ Robert L. Modlin, ${ }^{\ddagger 5}$ Daniel D. Bikle," and John S. Adams ${ }^{\star 5}$

${ }^{*}$ Departments of Medicine and ${ }^{\ddagger}$ Pathology, ${ }^{\S}$ Section of Dermatology and the ${ }^{\uparrow}$ Orthopaedic Hospital Bone and Connective Tissue Research Laboratory, University of Southern California School of Medicine, Los Angeles, California 90033; and the

Department of Medicine, Veterans Administration Medical Center, "University of California, San Francisco, California 94121

\section{Abstract}

We used tuberculous pleuritis as a model to study the compartmentalization and potential immunoregulatory role of 1,25-dihydroxyvitamin $\mathrm{D}\left[1,25-(\mathrm{OH})_{2}-\mathrm{D}\right]$ in human granulomatous disease. In tuberculous pleuritis, mean concentrations of total 1,25-(OH $)_{2}-\mathrm{D}$ were elevated in pleural fluid, compared to blood $(67 \mathrm{pg} / \mathrm{ml}$ vs. $35 \mathrm{pg} / \mathrm{ml})$. Concentrations of albumin, protein and 25-hydroxyvitamin D (25-OH-D) were lower in pleural fluid than blood, suggesting that accumulation of binding proteins does not explain the transpleural gradient of $1,25-(\mathrm{OH})_{2}-\mathrm{D}$. The mean free $1,25-(\mathrm{OH})_{2}$-D concentration in pleural fluid was increased 5.3-fold over that in serum. 1,25- $(\mathrm{OH})_{2}-\mathrm{D}_{3}$ inhibited PPD-induced proliferation of pleural fluid mononuclear cells, antigen-reactive lines and $T$ lymphocyte clones derived from a single cell. Patient-derived PPDreactive lines expressed a high-affinity intracellular binding moiety for $1,25-(\mathrm{OH})_{2}-\mathrm{D}_{3}$. Pleural fluid mononuclear cells and PPD-reactive lines did not metabolize $25-\mathrm{OH}-\mathrm{D}_{3}$ to $1,25-(\mathrm{OH})_{2}-D_{3}$. The sum of these data suggests that concentration of $1,25-(\mathrm{OH})_{2}-\mathrm{D}$ in pleural fluid of tuberculosis patients is probably due to local hormone production by pleural tissue-based inflammatory cells that are not present in significant numbers in pleural fluid. Elevated concentrations of $1,25-(\mathrm{OH})_{2}-\mathrm{D}$ in pleural fluid may exert receptor-mediated inhibition of antigen-induced proliferation by pleural fluid lymphocytes. Inhibition of lymphocyte proliferation and lymphokine production may prevent tissue destruction from an uncontrolled inflammatory response.

\section{Introduction}

The active metabolite of vitamin D, 1,25-dihydroxyvitamin D $\left[1,25-(\mathrm{OH})_{2}-\mathrm{D}\right]$, plays an important role in the pathogenesis of hypercalcemia associated with human granulomatous disease (1-6), and may have significant effects on the immune response in these diseases (7). Macrophages and lymphocytes at the site of tissue inflammation can metabolize 25-hydroxyvitamin $\mathrm{D}(25-\mathrm{OH}-\mathrm{D})^{1}$ to $1,25-(\mathrm{OH})_{2}-\mathrm{D}(8,9)$, suggesting that

Presented in part at the Seventh Workshop on Vitamin D, Rancho Mirage, CA, April 1988.

Address reprint requests to Dr. Barnes, HMR 904, University of Southern California School of Medicine, 2025 Zonal Avenue, Los Angeles, CA 90033.

Received for publication 15 July 1988 and in revised form $28 \mathrm{No}$ vember 1988 .

1. Abbreviations used in this paper: $\mathrm{DBP}$, vitamin $\mathrm{D}$ binding protein; $\mathrm{PPD}$, purified protein derivative; $25-\mathrm{OH}-\mathrm{D}, 25$-hydroxyvitamin $\mathrm{D}$

J. Clin. Invest.

(C) The American Society for Clinical Investigation, Inc.

$0021-9738 / 89 / 05 / 1527 / 06 \$ 2.00$

Volume 83, May 1989, 1527-1532
$1,25-(\mathrm{OH})_{2}$-D has important local immunoregulatory effects. In vitro, $1,25-(\mathrm{OH})_{2}-\mathrm{D}$ stimulates macrophage differentiation and hydrogen peroxide production (10-12), inhibiting mycobacterial growth in macrophages infected with Mycobacterium tuberculosis $(13,14)$. Although some evidence suggests that $1,25-(\mathrm{OH})_{2}-\mathrm{D}$ inhibits antigen-stimulated lymphocyte proliferation $(15,16)$ and lymphokine production $(17)$, stimulatory effects on these processes have also been observed $(18,19)$. Despite the in vitro data indicating a potential immunomodulatory role for $1,25-(\mathrm{OH})_{2}-\mathrm{D}$ in granulomatous diseases, direct evidence for the accumulation of $1,25-(\mathrm{OH})_{2}$ - $\mathrm{D}$ at inflammatory sites and immunoregulation by the hormone at these sites is lacking.

Tuberculous pleuritis provides an excellent model for studying the role in vivo of factors that modulate the cell-mediated immune response. Inflammatory cells and pleural fluid are readily obtained from the site of disease activity, and immunologic reactivity against the tubercle bacillus is compartmentalized in the pleural space. The frequency of purified protein derivative (PPD)-reactive T-lymphocytes is higher in pleural fluid than in peripheral blood (20), and interferongamma, a lymphokine with antimycobacterial activity, is selectively concentrated in the pleural space (21). In order to gain insight into the immunoregulatory potential of $1,25-(\mathrm{OH})_{2}-\mathrm{D}$ in vivo, we evaluated the compartmentalization and potential immunomodulatory role of $1,25-(\mathrm{OH})_{2}-\mathrm{D}$ in tuberculous pleural effusions. This was accomplished by assaying hormone concentrations in pleural fluid and serum, as well as by evaluating the effect of $1,25-(\mathrm{OH})_{2}-\mathrm{D}$ on lymphocyte proliferation to mycobacterial antigens.

\section{Methods}

Patient population. Pleural fluid and peripheral blood were obtained at the time of closed pleural biopsy or thoracentesis in 12 patients with newly diagnosed tuberculous pleuritis, seen at the Los Angeles County-University of Southern California Medical Center between December 1986 and October 1988. All patients had unilateral, exudative pleural effusions with a predominance of mononuclear cells. Five tuberculin unit PPD skin tests were positive (at least $10 \mathrm{~mm}$ induration) in 10 of 11 patients tested. Pleural biopsy revealed granulomatous pleuritis in nine cases. In the remaining three individuals, $M$. tuberculosis was cultured from pleural fluid or sputum. 11 patients had no risk factors for human immunodeficiency virus (HIV) infection. One patient had used intravenous drugs in the past and had a negative HIV antibody test by ELISA. All patients responded well to antituberculosis chemotherapy. None of the patients had evidence of the acquired immunodeficiency syndrome.

Peripheral blood samples were obtained from 9 patients with pulmonary tuberculosis, none of whom had concomitant pleural effusions. Sputum cultures yielded $M$. tuberculosis in all cases.

Pleural fluid and serum were also obtained from 13 patients with pleural effusions of nontuberculous etiology (malignancy, 7 cases; bacterial pneumonia, 3 cases; congestive heart failure, 2 cases; posttrauma, 1 case). 12 pleural fluid samples were exudates and one was transudative. 
In all cases, serum samples were collected within an hour of obtaining pleural fluid specimens. Hypercalcemia was not present in any of the patients studied.

Measurement of vitamin $D$ metabolite and protein concentrations. Samples of serum and pleural fluid were centrifuged at $2,500 \mathrm{rpm}$ for 10 minutes to pellet the cellular elements. Albumin and total protein concentrations in supernatants were determined colorimetrically. 25-OH-D concentrations were determined by competitive protein binding assay (22), and $1,25-(\mathrm{OH})_{2}-\mathrm{D}$ concentrations by $1,25-(\mathrm{OH})_{2}-\mathrm{D}$ receptor-ligand binding analysis according to the method of Reinhardt et al. (23). The intraassay coefficients of variation for the 25-OH-D and $1,25-(\mathrm{OH})_{2}-\mathrm{D}$ assays were 3.8 and $8.4 \%$, respectively. Free concentrations of $1,25-(\mathrm{OH})_{2}-\mathrm{D}$ were determined according to Hammond's centrifugal ultrafiltration isodialysis technique (24), as modified by Bikle et al. (25); free $1,25-(\mathrm{OH})_{2}-\mathrm{D}(\mathrm{fg} / \mathrm{ml})=$ total $1,25-(\mathrm{OH})_{2}-\mathrm{D}(\mathrm{pg} / \mathrm{ml})$ $\times 10^{3} \times$ free fraction of $1,25-(\mathrm{OH})_{2}-\mathrm{D}$. Vitamin $\mathrm{D}$ metabolite concentrations in all serum and pleural fluid samples were examined in a single assay.

Production of antigen-reactive T-lymphocyte lines and clones. Pleural fluid and peripheral blood mononuclear cells (PBMC) were isolated by centrifugation over Ficoll-Paque (Pharmacia Fine Chemicals, Piscataway, NJ). Mononuclear cells $\left(2 \times 10^{6} /\right.$ well $)$ were cultured in $7.5 \% \mathrm{CO}_{2}$ at $37^{\circ} \mathrm{C}$ in 24-well plates (Falcon Labware, Oxnard, CA) in the presence of $10 \mu \mathrm{g} / \mathrm{ml}$ of PPD, $10 \%$ AB serum (from normal donors with type AB blood) and RPMI 1640 (Gibco Laboratories, Grand Island, NY). After 5 d, cells were centrifuged over Ficoll-Paque to enrich for blasts, and fresh AB serum and 10\% IL2 (Electronucleonics, Silver Spring, MD) added. Thereafter, fresh AB serum and IL2 were added twice a week. To provide feeder and antigen-presenting cells, autologous irradiated $(2,500 \mathrm{rad}) \mathrm{PBMC} \cdot\left(5 \times 10^{5} /\right.$ well $)$ were added weekly and PPD given every $2 \mathrm{wk}$. Testing for proliferation was performed at least $3 \mathrm{~d}$ after addition of IL2 to the lines, and at least 1 wk after the addition of PPD.

Clones were established from antigen-reactive lines by Lamb's method of limiting dilution (26). Lymphoblasts were plated (0.3/well) in $200 \mu \mathrm{l}$ round-bottomed wells (Corning Glass Works, Corning, NY) in the presence of $10 \%$ IL2, $10 \%$ AB serum, $10 \mu \mathrm{g} / \mathrm{ml}$ of PPD and $10^{5}$ irradiated autologous PBMC/well. Fresh AB serum and IL2 were added twice a week, irradiated PBMC weekly, and PPD every 2 wks: Visible clones were expanded with IL2, PPD and irradiated autologous or HLA DR-matched donor PBMC. Testing for proliferation by $T$ cell clones was performed at least $3 \mathrm{~d}$ after they had received IL2 and a minimum of 1 wk after addition of antigen. All clones had stable phenotypes and antigen-reactivity patterns for over $6 \mathrm{mo}$ in culture.

$1,25-(\mathrm{OH})_{2}-\mathrm{D}_{3}$ receptors in antigen-reactive lines. Six PPD-reactive mononuclear cell lines (three from pleural fluid of patients with tuberculous pleuritis and three from blood of pulmonary tuberculosis patients) were evaluated for specific uptake and receptor binding of $\left[{ }^{3} \mathrm{H}\right]-1,25-(\mathrm{OH})_{2}-\mathrm{D}_{3}$, as previously described (27). Briefly, cells were washed twice in serum-free RPMI 1640 and cell suspensions $\left(5 \times 10^{6}\right.$ cells/ml) incubated with 0.12 to $2 \mathrm{nM}\left[{ }^{3} \mathrm{H}\right]-1,25-(\mathrm{OH})_{2}-\mathrm{D}_{3}$ (specific activity $181 \mathrm{Ci} / \mathrm{mM}$; Amersham Corp., Arlington Heights, IL) in the

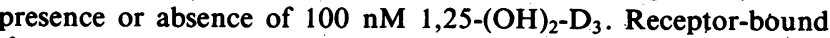
$\left[{ }^{3} \mathrm{H}\right]-1,25-(\mathrm{OH})_{2}-\mathrm{D}_{3}$ was separated from unbound (free) hormone on DEAE cellulose filters. Specifically internalized (bound) hormone is expressed as the difference between the cellular uptake of $\left[{ }^{3} \mathrm{H}\right]-1,25$ $(\mathrm{OH})_{2}-\mathrm{D}_{3}$ in the absence and presence of $\left.100 \mathrm{nM} \mathrm{1,25-(OH}\right)_{2}-\mathrm{D}_{3}$ in the incubation medium.

Effect of vitamin $D$ metabolites on lymphocyte proliferation. Authentic, crystalline 25-OH-D was generously provided by Dr. John Babcock (Upjohn Co., Kalamazoo, MI). 1,25-(OH) $)_{2}-\mathrm{D}_{3}$ and 24,25$(\mathrm{OH})_{2}-\mathrm{D}_{3}$ were provided by Dr. Milan Uskokovic (Hoffmann-LaRoche, Inc., Nutley, NJ). Vitamin D sterols were solubilized in absolute ethanol. To assess the effect of vitamin D metabolites on PPD-induced proliferation by freshly isolated mononuclear cells from pleural fluid or peripheral blood, $10^{5}$ cells were placed in $200 \mu$ l flat-bottomed wells containing RPMI $1640,10 \%$ AB serum, $10 \mu \mathrm{g} / \mathrm{ml}$ of PPD, and vitamin D metabolites as a $0.02 \%$ solution in ethanol in concentrations

ranging from $10^{-8}$ to $10^{-10} \mathrm{M}$. All assays were performed in triplicate. In six control wells (three with PPD, three with media alone), no vitamin D metabolites were added. After $5 \mathrm{~d}, 1 \mu \mathrm{Ci}$ of $\left[{ }^{3} \mathrm{H}\right]$ thymidine was added to each well and the cells harvested $18 \mathrm{~h}$ later with a semiautomated cell harvester (FACS IV; Cambridge Technology, Cambridge, MA). Radioactivity incorporation was measured by liquid scintillation spectroscopy.

Proliferation assays on $\mathrm{T}$ cell lines and clones were performed in the same manner as for freshly isolated mononuclear cells, with the exception that $10^{4}$ lymphoblasts and $10^{5}$ irradiated autologous or donor DR-matched PBMC were used instead of $10^{5}$ mononuclear cells. $\left[{ }^{3} \mathrm{H}\right]$ Thymidine was added after $72 \mathrm{~h}$ and the cells harvested $4 \mathrm{~h}$ later.

Metabolism of 25-OH- $\mathrm{D}_{3}$ by mononuclear cells. Using a modification of our previously described procedure (1), freshly isolated pleura fluid mononuclear cells and PPD-reactive lines from pleural fluid and blood were studied for their capacity to metabolize $\left[{ }^{3} \mathrm{H}\right]-25-\mathrm{OH}-\mathrm{D}_{3}$ (specific activity $181 \mathrm{Ci} / \mathrm{mM}$ ) to a compound cochromatographing with $1,25-(\mathrm{OH})_{2}-\mathrm{D}_{3}$. Cells were washed twice in serum-free medium, and plated at $2 \times 10^{6}$ cells $/ \mathrm{ml}$ in 24-well plates $(1 \mathrm{ml} /$ well $)$ in RPMI 1640 containing $10.5 \%$ fetal calf serum (Gibco Laboratories), with or without $500 \mathrm{IU} / \mathrm{ml}$ of recombinant human interferon-gamma (Collaborative Research Inc., Bedford, MA). After preincubation for 6 hours the cells were exposed to $5 \mathrm{nM}\left[{ }^{3} \mathrm{H}\right]-25-\mathrm{OH}-\mathrm{D}_{3}$, solubilized in $0.02 \%$ ethanol, for periods ranging from 3 to $8 \mathrm{~h}$. Incubation with substrate $\left[{ }^{3} \mathrm{H}\right]-25-\mathrm{OH}-\mathrm{D}_{3}$ was terminated by addition of methanol containing 50 ng $1,25-(\mathrm{OH})_{2}-\mathrm{D}_{3}$; radioinert $1,25-(\mathrm{OH})_{2}-\mathrm{D}_{3}$ was employed to monitor recovery of metabolite cochromatographing with $1,25-(\mathrm{OH})_{2}-\mathrm{D}_{3}$. Lipid extraction of the cells and culture medium was performed. The extracts were subjected to chromatography on silica Sep-Pak cartridges (Millipore-Waters, Milford, MA) (28) and normal phase high performance liquid chromatography for isolation and quantification of metabolite which cochromatographed with $1,25-(\mathrm{OH})_{2}-\mathrm{D}_{3}(8)$.

Statistical analysis. Student's $t$ test (paired where appropriate) was used to evaluate the statistical significance of comparisons made. Coefficients of correlation were determined according to the method of least squares.

\section{Results}

Vitamin D metabolite concentration in pleural fluid and serum. In order to determine if there was accumulation of $1,25-(\mathrm{OH})_{2}-\mathrm{D}$ at the site of tissue inflammation, we measured total hormone concentrations in pleural fluid and serum of patients with tuberculous pleuritis. Fig. 1 demonstrates that $1,25-(\mathrm{OH})_{2}-\mathrm{D}$ was selectively concentrated in the pleural fluid of patients with tuberculous pleuritis, but not in those with other diseases. In patients with tuberculosis, the mean concen-

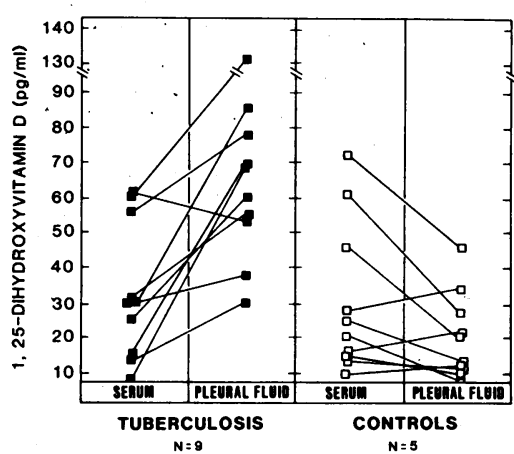

$\mathrm{pg} / \mathrm{ml} ; P<0.001)$. In non-tuberculous effusions, mean $1,25-(\mathrm{OH})_{2}-\mathrm{D}$ concentrations in pleural fluid and serum are not significantly different $(20 \pm 6 \mathrm{pg} / \mathrm{ml}$ vs. $33 \pm 13.7 \mathrm{pg} / \mathrm{ml} ; P=0.56)$. 
tration of total hormone in pleural fluid was $100 \%$ higher than that in serum. In three additional patients with nontuberculous effusions, 1,25- $(\mathrm{OH})_{2}$-D levels in pleural fluid were 8, 22, and $23 \mathrm{pg} / \mathrm{ml}$. Serum samples were not available in these three cases.

To determine whether the transpleural gradient of $1,25-(\mathrm{OH})_{2}-\mathrm{D}$ in tuberculous pleuritis resulted from elevated levels of protein with $1,25-(\mathrm{OH})_{2}-\mathrm{D}$ binding capacity in pleural fluid, protein and albumin concentrations in serum and pleural fluid of these patients were examined. Mean total protein concentrations in pleural fluid and serum were 5.3 and 6.9 $\mathrm{g} / \mathrm{dl}$, respectively $(P<0.001)$. Mean albumin levels in these two compartments were 2.5 and $3.7 \mathrm{~g} / \mathrm{dl}$, respectively $(P$ $<0.002$ ). Thus, compared to serum, total protein and albumin levels were significantly reduced in pleural fluid, suggesting that albumin, which normally binds $15-25 \%$ of total $1,25-(\mathrm{OH})_{2}-\mathrm{D}(25)$, was not the binding moiety maintaining high pleural fluid concentrations of $1,25-(\mathrm{OH})_{2}-\mathrm{D}$ in tuberculosis patients. Although pleural fluid total protein concentrations were lower than those of serum, this does not exclude preferential accumulation of a specific vitamin $\mathrm{D}$ binding protein (DBP) in pleural fluid of tuberculosis patients. As an indirect assessment of this possibility, concentrations of 25-OH-D, the natural substrate for $1,25-(\mathrm{OH})_{2}-\mathrm{D}$, were measured; circulating DBP binds $25-\mathrm{OH}-\mathrm{D}$ with higher affinity than $1,25-(\mathrm{OH})_{2}-\mathrm{D}$. Thus, if preferential accumulation of DBP in pleural fluid accounts for the high $1,25-(\mathrm{OH})_{2}$-D concentrations in tuberculous pleuritis, one would expect 25-OH-D levels in pleural fluid to be higher than those in serum. However, mean total $25-\mathrm{OH}-\mathrm{D}$ concentrations were relatively reduced in pleural fluid, compared to serum (19.7 vs. 28.3 $\mathrm{ng} / \mathrm{ml}$, respectively). Expressed as a ratio of 1,25-(OH $)_{2}-\mathrm{D}: 25-$ $\mathrm{OH}-\mathrm{D}$, the mean product:substrate ratio was 2.7 -fold higher in pleural fluid, compared to serum $\left(3.8 \times 10^{-3}\right.$ vs. $1.4 \times 10^{-3}$, respectively). These data indicate that pleural accumulation of $1,25-(\mathrm{OH})_{2}-\mathrm{D}$ in tuberculosis is metabolite-specific for $1,25-(\mathrm{OH})_{2}-\mathrm{D}$ and not related to preferential partitioning of vitamin $\mathrm{D}$ metabolite binding proteins. It is interesting to note that the concentration of $1,25-(\mathrm{OH})_{2}-\mathrm{D}$ and $25-\mathrm{OH}-\mathrm{D}$ were positively correlated $(r=0.68, P<0.02)$ in the pleural fluid but not in the serum $(r=0.14)$ of patients with tuberculous pleuritis. This observation suggests that the concentration of $1,25-(\mathrm{OH})_{2}-\mathrm{D}$ may be dependent on the concentration of substrate $25-\mathrm{OH}-\mathrm{D}$ in the pleural fluid of these patients.

It is presumed that the biologic effects of $1,25-(\mathrm{OH})_{2}-\mathrm{D}$ are mediated by the small fraction of hormone that is not bound by vitamin $\mathrm{D}$ metabolite binding proteins. To determine if the elevated total levels of $1,25-(\mathrm{OH})_{2}-\mathrm{D}$ reflected those of unbound hormone, we measured free $1,25-(\mathrm{OH})_{2}-\mathrm{D}$ concentrations in 7 patients with tuberculous pleuritis and 3 individuals with nontuberculous effusions (Fig. 2). The mean free concentration of $1,25-(\mathrm{OH})_{2}$-D in pleural fluid was increased 5.3-fold over that in serum of tuberculosis patients and was 3.6-fold greater than the mean concentration detected in pleural fluid of patients with nontuberculous effusions.

$1,25-(\mathrm{OH})_{2}-\mathrm{D}$ receptors in antigen-reactive $\mathrm{T}$ lymphocyte lines. Receptors for $1,25-(\mathrm{OH})_{2}$ - $\mathrm{D}$ have previously been demonstrated in activated and transformed lymphocytes $(29,30)$. To evaluate the possible immunoregulatory role of $1,25-(\mathrm{OH})_{2}-\mathrm{D}$ on lymphocytes in tuberculosis, we examined the potential for mononuclear cells from pleural fluid and peripheral blood of tuberculosis patients to express the recep-

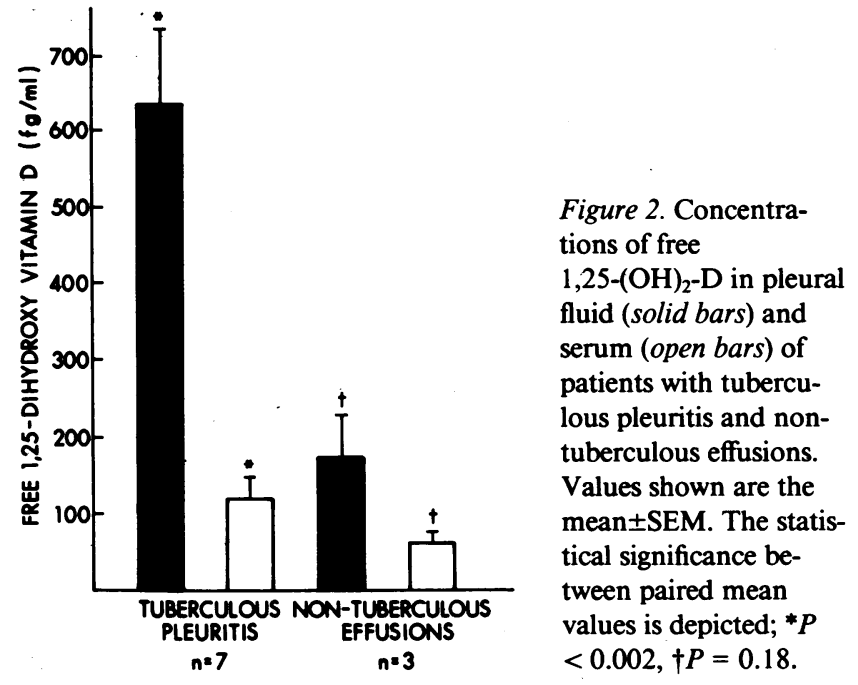

tor for 1,25-(OH $)_{2}$-D after activation with mycobacterial antigen (PPD) in vitro (Fig. 3). PPD-reactive mononuclear cell lines from both pleural fluid and blood expressed a high-affinity intracellular binding moiety for $1,25-(\mathrm{OH})_{2}-\mathrm{D}_{3}$. Although differing up to fivefold in terms of overall binding capacity, the receptor was identified in cell lines from both pleural fluid and peripheral blood. These data suggest that activation with PPD confers on these cells a mechanism to respond to 1,25 $(\mathrm{OH})_{2}$-D.

Effect of vitamin $D$ metabolites on lymphocyte proliferation. To ascertain if vitamin D metabolites or the ethanol used to solubilize them were toxic to cells in culture, we performed preliminary experiments to address these questions. Lymphocyte proliferation was unaffected by the addition of $0.02 \%$ ethanol. Cell viability, assessed by trypan blue exclusion, was not affected by addition of ethanol or any of the vitamin D metabolites. Fig. $4 A$ shows the effects of vitamin D metabo-
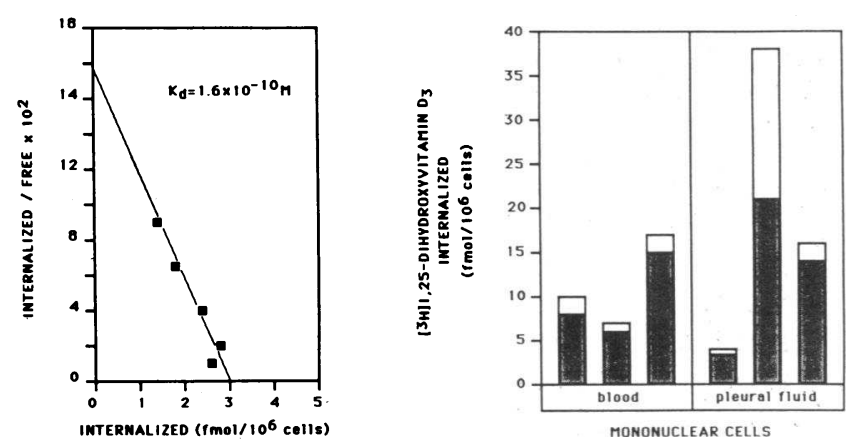

Figure 3. (A) A Scatchard plot of the specific internalization and receptor binding of $1,25-(\mathrm{OH})_{2}-\mathrm{D}_{3}$ by PPD-activated mononuclear cell lines established from the pleural fluid of a patient with tuberculous pleuritis. The dissociation constant $\left(K_{d}\right)$ for hormone internalization and receptor binding is shown. Each point is the mean value of duplicate determinations of specific binding. $(B)$ Total and specific internalization (shaded area) of $1 \mathrm{nM}\left[{ }^{3} \mathrm{H}\right]-1,25-(\mathrm{OH})_{2}-\mathrm{D}_{3}$ by PPD-activated mononuclear cell lines established from the pleural fluid and peripheral blood of six patients with tuberculosis. Each value for total and specific uptake of $\left[{ }^{3} \mathrm{H}\right]-1,25-(\mathrm{OH})_{2}-\mathrm{D}_{3}$ is the mean of triplicate determinations. All cell lines were assayed 10-14 d after addition of PPD. 


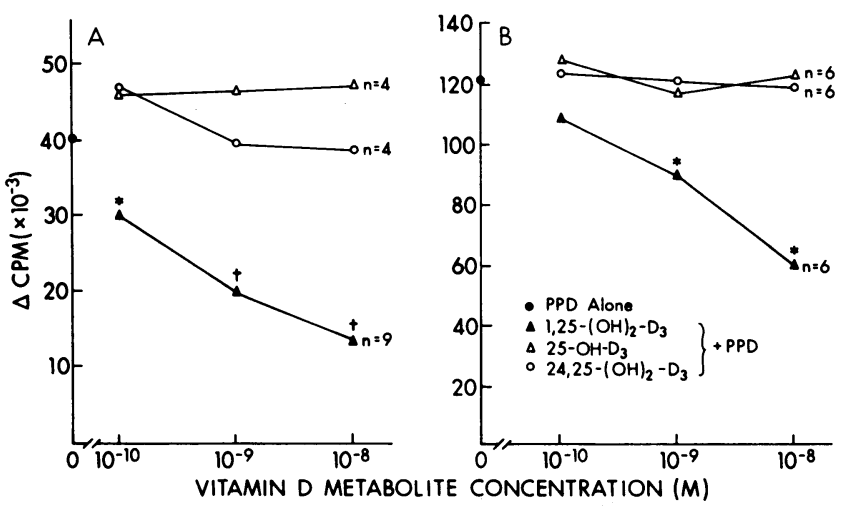

Figure 4. Effect of 1,25-(OH) $)_{2}$-D on PPD-induced proliferation by mononuclear cells from patients with tuberculosis. Mean values are displayed. All assays were performed in triplicate and the standard error for each determination ranged from 0.5 to $15 \%$ (mean $7 \%$ ). $(A)$ Proliferation by PBMC from patients with pulmonary tuberculosis. Counts per minute with media alone $=650 \pm 290$. $(B)$ Proliferation by pleural fluid mononuclear cells from patients with tuberculous pleuritis. Counts per minute with media alone $=2,364 \pm 1,142 .{ }^{*} 0.01$ $<P<0.05$, compared to delta cpm with PPD alone. $\dagger P=0.001$, compared to delta cpm with PPD alone.

lites on PPD-induced proliferation by PBMC from nine patients with pulmonary tuberculosis. Concentrations of $1,25-(\mathrm{OH})_{2}-\mathrm{D}_{3}$ as low as $10^{-10} \mathrm{M}$ resulted in significantly decreased proliferation, and increasing concentrations had incremental antiproliferative effects. $25-\mathrm{OH}-\mathrm{D}_{3}$ and $24,25-$ $(\mathrm{OH})_{2}-\mathrm{D}_{3}$, in concentrations of up to $10^{-8} \mathrm{M}$, did not decrease lymphocyte proliferation. In freshly isolated pleural fluid mononuclear cells, $1,25-(\mathrm{OH})_{2}-\mathrm{D}_{3}$, but not other vitamin $\mathrm{D}$ metabolites, again inhibited PPD-induced proliferation in a concentration-dependent fashion (Fig. $4 B$ ). In three pleural fluid-derived PPD-reactive lines (data not shown) and in two pleural fluid-derived $T$ lymphocyte clones, $1,25-(\mathrm{OH})_{2}-\mathrm{D}_{3}$ inhibited T-cell proliferation at concentrations of $10^{-9} \mathrm{M}$ (Table I).

Table I. $\left[{ }^{3} \mathrm{H}\right]$ Thymidine Incorporation by Pleural Fluid-derived T Lymphocyte Clones

\begin{tabular}{lcrr}
\hline Antigen & $\begin{array}{c}1,25-(\mathrm{OH})_{2}-\mathrm{D}_{3} \\
\text { concentration }\end{array}$ & \multicolumn{2}{c}{ Clone } \\
\hline & $M$ & RP3 & \multicolumn{1}{c}{ RP5 } \\
None & 0 & 3,909 & 1,673 \\
PPD & 0 & 79,805 & 14,984 \\
PPD & $10^{-10}$ & 72,691 & 15,639 \\
PPD & $10^{-9}$ & 68,919 & 6,147 \\
PPD & $10^{-8}$ & 41,229 & 3,475
\end{tabular}

$10^{4}$ cloned $\mathrm{T}$ lymphocytes derived from pleural fluid were placed in $200 \mu \mathrm{l}$ flat-bottomed wells containing $10 \%$ human AB serum, 10 $\mu \mathrm{g} / \mathrm{ml}$ of $\mathrm{PPD}$, and $1,25-(\mathrm{OH})_{2}-\mathrm{D}_{3}$ in varying concentrations. All assays were performed in triplicate. In control wells (three with PPD, three with media alone), no vitamin D metabolites were added. After $3 \mathrm{~d}, 1 \mu \mathrm{Ci}$ of $\left[{ }^{3} \mathrm{H}\right]$ thymidine was added to each well and the cells harvested $4 \mathrm{~h}$ later with a semiautomated cell harvester. Radioactivity incorporation was measured by liquid scintillation spectroscopy. All values in the table are shown as mean counts per minute.
Metabolism of $25-\mathrm{OH}-\mathrm{D}_{3}$ by mononuclear cells. In an attempt to identify the cellular source of $1,25-(\mathrm{OH})_{2}-\mathrm{D}$ production in the pleural space, we evaluated the ability of freshly isolated pleural fluid cells and antigen-activated cell lines to metabolize $25-\mathrm{OH}-\mathrm{D}_{3}$ to more polar compounds. The $\left[{ }^{3} \mathrm{H}\right]-25-\mathrm{OH}-\mathrm{D}_{3}$ metabolic capacity was examined in freshly isolated mononuclear cells from pleural fluid of three patients with tuberculous pleuritis, PPD-reactive cell lines from pleural fluid of three patients with tuberculous pleuritis, and peripheral blood of three individuals with pulmonary tuberculosis. In each case, we were unable to detect production of a labelled metabolite of $\left[{ }^{3} \mathrm{H}\right]-25-\mathrm{OH}-\mathrm{D}_{3}$ that cochromatographed with authentic $1,25-(\mathrm{OH})_{2}-\mathrm{D}_{3}$ or $24,25-(\mathrm{OH})_{2}-\mathrm{D}_{3}$.

\section{Discussion}

The data presented in this investigation demonstrate selective accumulation of $1,25-(\mathrm{OH})_{2}$-D in vivo at an inflammatory site in human disease. A potential explanation for this selective concentration of $1,25-(\mathrm{OH})_{2}-\mathrm{D}$ in pleural fluid in tuberculous pleuritis is the accumulation of vitamin $\mathrm{D}$ metabolite binding proteins in the pleural space. However, the fact that free $1,25-(\mathrm{OH})_{2}-\mathrm{D}$ concentrations are elevated in pleural fluid, while $25-\mathrm{OH}-\mathrm{D}$ concentrations are not, strongly suggests that accumulation of binding proteins is unlikely to explain the transpleural gradient of $1,25-(\mathrm{OH})_{2}-\mathrm{D}$. We believe that selective pleural concentration of $1,25-(\mathrm{OH})_{2}-\mathrm{D}$ in tuberculous pleuritis is most likely to result from local hormone production by activated inflammatory cells in or adjacent to the pleural space. This hypothesis is supported by the existence of a positive correlation between the concentration of substrate $(25-\mathrm{OH}-\mathrm{D})$ and product $\left[1,25-(\mathrm{OH})_{2}-\mathrm{D}\right]$ in pleural fluid of patients with tuberculous pleuritis. We were unable to demonstrate hormone production by activated mononuclear cells in pleural fluid or peripheral blood of tuberculosis patients, suggesting that the synthetic source of $1,25-(\mathrm{OH})_{2}-\mathrm{D}$ is not present in pleural fluid-derived cells studied in vitro. However, preliminary data indicate that tuberculous effusions contain a factor that promotes 25-OH-D-1-hydroxylation by heterologous pulmonary alveolar macrophages (Adams, J., unpublished observations). We cannot exclude the possibility that $1,25-(\mathrm{OH})_{2}-\mathrm{D}$ production occurring in vivo does not take place under conditions employed in vitro or that there is decreased catabolism of $1,25-(\mathrm{OH})_{2}-\mathrm{D}$ in the pleural space. However, these possibilities are less likely as we and others have previously demonstrated $1,25-(\mathrm{OH})_{2}$-D and $24,25-(\mathrm{OH})_{2}-\mathrm{D}$ production by inflammatory cells from patients with granulomatous diseases under culture conditions similar to those used in the present investigation $(8,9)$.

We believe that our results are best explained by the hypothesis that $1,25-(\mathrm{OH})_{2}-\mathrm{D}$ is produced by pleural tissue-based inflammatory cells that are not present in significant numbers in pleural fluid. Activated macrophages and/or lymphocytes are potential candidates for this role as they possess the cellular machinery to produce $1,25-(\mathrm{OH})_{2}-\mathrm{D}(8,9,31)$ and are the predominant cells in the pleural granulomata where the inflammatory response is most intense. In this microanatomic environment, concentrations of $1,25-(\mathrm{OH})_{2}-\mathrm{D}$ may be far higher than those observed in pleural fluid, enhancing the hormone's local antiproliferative effects. Once formed in 
pleural tissue, $1,25-(\mathrm{OH})_{2}-\mathrm{D}$ can diffuse into the pleural space or the general circulation. Since the intravascular space has a much greater volume of distribution than the pleural space, hormone concentrations in pleural fluid are greater than those in serum. Accumulation of $1,25-(\mathrm{OH})_{2}-\mathrm{D}$ in the pleural space was not found in patients with malignancy or parapneumonic effusions. Because of the small number of cases of parapneumonic effusion studied, it remains uncertain if pleural concentration of $1,25-(\mathrm{OH})_{2}-\mathrm{D}$ is specific for tuberculosis or whether it is seen in other infectious processes.

Tuberculous pleuritis is characterized by a marked local hypersensitivity response to mycobacterial antigens, even though the bacillary load is generally low $(32,33)$. In this setting, lymphocyte proliferation and lymphokine production may result in an uncontrolled inflammatory response that causes undue host tissue destruction. 1,25-(OH) 2 -D may limit this response by acting as a brake on the immune system. We have demonstrated that $1,25-(\mathrm{OH})_{2}-\mathrm{D}_{3}$ has the potential to exert powerful, receptor-mediated inhibitory effects on antigen-induced proliferation by pleural fluid lymphocytes, at the level of freshly isolated cells, antigen-reactive lines, and Tlymphocyte clones derived from a single cell. Under culture conditions utilizing $10 \%$ human serum, antiproliferative effects were observed at total $1,25-(\mathrm{OH})_{2}-\mathrm{D}_{3}$ concentrations of $10^{-10} \mathrm{M}$. Since $\sim 4 \%$ of total $1,25-(\mathrm{OH})_{2}-\mathrm{D}_{3}$ is free under these conditions (24), free $1,25-(\mathrm{OH})_{2}$-D levels would be in the range of $4 \times 10^{-12} \mathrm{M}$ or $1,600 \mathrm{fg} / \mathrm{ml}$. In tuberculous pleuritis, mean free $1,25-(\mathrm{OH})_{2}-\mathrm{D}$ concentrations in pleural fluid were over $600 \mathrm{fg} / \mathrm{ml}$ and thus could be high enough to exert an immunoinhibitory effect in vivo. Free $1,25-(\mathrm{OH})_{2}$-D concentrations in the local microanatomic environment of the inflammatory site are likely to be higher than those measured in pleural fluid.

$1,25-(\mathrm{OH})_{2}$-D stimulates macrophage differentiation (11), giant cell formation (10), and hydrogen peroxide production (12). In addition, 1,25-(OH $)_{2}-\mathrm{D}$ has recently been shown to inhibit growth of Mycobacterium tuberculosis in macrophages $(13,14)$. It is intriguing to speculate that elevated $1,25-(\mathrm{OH})_{2}-$ $\mathrm{D}$ concentrations in the pleural space may facilitate the ingestion and elimination of mycobacteria through enhancing macrophage function. Thus, $1,25-(\mathrm{OH})_{2}-\mathrm{D}$ has the potential both to stimulate cell-mediated immune defenses against mycobacteria while limiting host tissue destruction due to uncontrolled lymphocyte proliferation. Further studies of the complex interactions between $1,25-(\mathrm{OH})_{2}-\mathrm{D}, M$. tuberculosis and the human immune system will provide important insight into the immunoregulatory role of this hormone in human granulomatous diseases.

\section{Acknowledgments}

We thank Drs. Thomas Verdegem, Jeffrey Fried, Kamlesh Pandya and Charanjit Lal for their assistance in obtaining pleural fluid and tissue specimens, and Mercedes Gacad, Marie Diz, and Sameer Mistry for technical assistance.

This work was supported in part by grant DK-33139 from the National Institutes of Health, the World Health Organization's Programme for Vaccine Development (IMMTUB), and the national and local branches of the American Lung Association. Computational assistance was provided by the CLINFO project, funded by the General Clinical Research Centers Program of the Division of Research Resources (Mo1-RR-43)

\section{References}

1. Adams, J. S., F. R. Singer, M. A. Gacad, O. P. Sharma, M. J. Hayes, P. Vouros, and M. F. Holick. 1985. Isolation and structural identification of 1,25-dihydroxyvitamin $\mathrm{D}_{3}$ produced by cultured alveolar macrophages in sarcoidosis. J. Clin. Endocrinol. Metab. 60:960-966.

2. Gnokos, P. J., R. London, and E. D. Hendler. 1984. Hypercalcemia and elevated 1,25-dihydroxyvitamin D levels in a patient with end-stage renal disease and active tuberculosis. N. Engl. J. Med. 311:1683-1685.

3. Bell, N. H., J. Shary, S. Shaw, and R. T. Turner. 1985. Hypercalcemia associated with increased circulating 1,25-dihydroxyvitamin $\mathrm{D}$ in a patient with pulmonary tuberculosis. Calcif. Tissue Int. 37:588-591.

4. Kantarjian, H. M., M. F. Saad, E. H. Estey, R. V. Sellin, and N. A. Samaan. 1983. Hypercalcemia in disseminated candidiasis. Am. J. Med. 74:721-724.

5. Hoffman, V. N., and O. M. Korzeniowski. 1986. Leprosy, hypercalcemia and elevated serum calcitriol levels. Ann. Intern. Med. 105:890-891.

6. Kozeny, G. A., A. L. Barbato, V. K. Bansal, L. L. Vertuno, and J. E. Hano. 1984. Hypercalcemia associated with silicone-induced granulomas. N. Engl. J. Med. 311:1103-1105.

7. Rigby, W. F. C. 1988. The immunobiology of vitamin D. Immunol. Today. 9:54-58.

8. Adams, J. S., and M. A. Gacad. 1985. Characterization of 1 alpha-hydroxylation of vitamin $\mathrm{D}_{3}$ sterols by cultured alveolar macrophages from patients with sarcoidosis. J. Exp. Med. 161:755-765.

9. Cadrenel, J., M. Garabedian, and A. Hance. 1988. 1,25(OH $)_{2} \mathrm{D}_{3}$ production by lung $\mathrm{T}$ lymphocytes from tuberculosis patients. $A b$ stracts of the Seventh Workshop on Vitamin D. 7:207. (Abstr.)

10. Abe, E., Y. Shiina, C. Miyaura, H. Tanaka, T. Hayashi, S. Kanegasaki, M. Saito, Y. Nishii, H. F. DeLuca, and T. Suda. 1984. Activation and fusion induced by 1 alpha,25-dihyroxyvitamin $\mathrm{D}_{3}$ and their relation in alveolar macrophages. Proc. Natl. Acad. Sci. USA. 81:7112-7116.

11. Amento, E. P., A. K. Bhalla, J. T. Kurnick, R. L. Kradin, T. L. Clemens, S. A. Holick, M. F. Holick, and S. M. Krane. 1984. 1 alpha,25-dihydroxyvitamin $D_{3}$ induces maturation of the human monocyte cell line U937, and, in association with a factor from human $T$ lymphocytes, augments production of the monokine, mononuclear cell factor. J. Clin. Invest. 73:731-739.

12. Cohen, M. S., D. E. Mesler, R. G. Snipes, and T. K. Gray. 1986. 1,25-dihydroxyvitamin $\mathrm{D}_{3}$ activates secretion of hydrogen peroxide by human monocytes. J. Immunol. 136:1049-1053.

13. Rook, G. A. W., J. Steele, L. Fraher, S. Barker, R. Karmali, and J. O'Riordan. 1986. Vitamin $D_{3}$, gamma interferon, and control of proliferation of Mycobacterium tuberculosis by human monocytes. Immunology. 57:159-163.

14. Crowle, A. J., E. J. Ross, and M. H. May. 1987. Inhibition by $1,25-(\mathrm{OH})_{2}$-vitamin $\mathrm{D}_{3}$ of the multiplication of virulent tubercle bacilli in cultured human macrophages. Infect. Immun. 55:2945-2950.

15. Lemire, J. M., J. S. Adams, R. Sakai, and S. C. Jordan. 1984. 1 alpha,25-dihydroxyvitamin $\mathrm{D}_{3}$ suppresses proliferation and immunoglobulin production by normal human peripheral blood mononuclear cells. J. Clin. Invest. 74:657-661.

16. Bhalla, A. K., E. P. Amento, B. Serog, and L. H. Glimcher. 1984. 1,25-dihydroxyvitamin $D_{3}$ inhibits antigen-induced $T$ cell activation. J. Immunol. 133:1748-1754.

17. Rigby, W. F. C., T. Stacy, and M. W. Fanger. 1984. Inhibition of $\mathrm{T}$ lymphocyte mitogenesis by 1,25-dihydroxyvitamin $\mathrm{D}_{3}$ (Calcitriol). J. Clin. Invest. 74:1451-1455.

18. Lacey, D. L., J. Axelrod, J. C. Chappel, A. J. Kahn, and S. L. Teitelbaum. 1987. Vitamin D affects proliferation of a murine $T$ helper cell clone. J. Immunol. 138:1680-1686. 
19. Manolagas, S. C., D. M. Provvedini, D. J. Young, and C. D. Tsoukas. 1988. At physiologic concentrations, 1,25-dihydroxyvitamin $\mathrm{D}_{3}$ acts directly on T-cells to stimulate y-IFN. Abstracts of the Seventh Workshop on Vitamin D. 7:72. (Abstr.)

20. Fujiwara, H., and I. Tsuyuguchi. 1986. Frequency of tuberculin-reactive T-lymphocytes in pleural fluid and blood from patients with tuberculous pleurisy. Chest. 89:530-532.

21. Barnes, P. F., S. D. Mistry, C. L. Cooper, C. Pirmez, T. H. Rea, and R. L. Modlin. 1988. Compartmentalization of a CD4+ T lymphocyte subpopulation in tuberculous pleuritis. J. Immunol. 142:1114-1119.

22. Preece, M. A., J. L. O'Riordan, D. E. Lawson, and E. Kodicek. 1974. A competitive protein-binding assay for 25 -hydroxycholecalciferol and 25-hydroxyergocalciferol. Clin. Chim. Acta. 54:235-242.

23. Reinhardt, T. A., R. L. Horst, J. W. Orf, and B. W. Hollis. 1984. A microassay for 1,25-dihydroxyvitamin $D$ not requiring high performance liquid chromatography: Application to clinical studies. J. Clin. Endocrinol. Metab. 58:91-98.

24. Hammond, G. L., J. A. Nisker, L. A. Jones, and P. K. Siiteri. 1980. Estimation of the percentage of free steroid in undiluted serum by centrifugal ultrafiltration-dialysis. J. Biol. Chem. 255:5023-5026.

25. Bikle, D. D., P. K. Siiteri, E. Ryzen, and J. G. Haddad. 1985. Serum protein binding of 1,25-dihydroxyvitamin D: A reevaluation by direct measurement of free metabolite levels. J. Clin. Endocrinol. Metab. 61:969-975.

26. Lamb, J. R., D. D. Eckels, P. Lake, A. H. Johnson, R. J.
Hartzman, and J. N. Woody. 1982. Antigen-specific human T lymphocyte clones: induction, antigen specificity, and MHC restriction of influenza virus-immune clones. J. Immunol. 128:233-238.

27. Adams, J. S., and M. A. Gacad. 1988. Phenotypic diversity of the cellular 1,25-dihydroxyvitamin $D_{3}$-receptor interaction among different genera of New World primates. J. Clin. Endocrinol. Metab. 66:224-229.

28. Adams, J. S., T. L. Clemens, and M. F. Holick. 1981. Silica Sep-Pak preparative chromatography for vitamin D and its metabolites. J. Chromatogr. 226:198-201.

29. Provvedini, D. M., C. D. Tsoukas, L. J. Deftos, and S. C. Manolagas. 1983. 1,25 dihydroxyvitamin $D_{3}$ receptors in human leukocytes. Science (Wash. DC). 221:1181-1183.

30. Bhalla, A. K., E. P. Amento, T. R. Clemens, M. F. Holick, and S. M. Krane. 1983. Specific high affinity receptors for 1,25 -dihydroxyvitamin $D_{3}$ in human peripheral blood mononuclear cells: presence in monocytes and induction in $\mathrm{T}$ lymphocytes following activation. $J$. Clin. Endocrinol. Metab. 57:1302-1310.

31. Reichel, H., H. P. Koeffler, and A. W. Norman. 1987. 25-hydroxyvitamin $\mathrm{D}_{3}$ metabolism by human T-lymphotropic virus-transformed lymphocytes. J. Clin. Endocrinol. Metab. 65:519-526. (Abstr.)

32. Allen, J. C., and M. A. Apicella. 1968. Experimental pleural effusion as a manifestation of delayed hypersensitivity to tuberculin PPD. J. Immunol. 101:481-487.

33. Berger, H. W., and E. Mejia. 1973. Tuberculous pleurisy. Chest. 63:88-92. 